\title{
PERUBAHAN RUANG SAKRAL WILAYAH KUTA, BALI
}

\author{
Ari Djatmiko', Zulphiniar Priyandhoko ${ }^{2}$ \\ Program Studi Perencanaan Wilayah \& Kota, Fakultas Teknik. Universitas Pasundan \\ Bandung \\ Jl. Dr. Setiabudhi No. 193 Bandung \\ *Email: ${ }^{1}$ aridjat@gmail.com, ${ }^{2}$ zulphiniar@gmail.com
}

\begin{abstract}
ABSTRAK
Ruang sakral dinyatakan sebagai bangunan atau obyek utama yang memiliki nilai sakral. Perubahan ruang sakral dapat dinilai dari sisi internal sebagai adanya perubahan unsur-unsur fisik pada ruang atau obyek tersebut seperti perubahan fungsi baik penambahan ataupun pengurangan; perubahan tata letak dan orientasi serta perubahan luas ruang. Selain itu perubahan ruang sakral dapat dinyatakan pula dari sisi eksternal dengan mempertimbangkan perubahan ruang sekitarnya/berbatasan yang dapat mempengaruhi nilai kesakralan bangunan atau obyek sakralnya, seperti perubahan radius jarak dengan bangunan terdekat, perubahan ketinggian bangunan terdekat dan daya pandang bangunan terdekat ke arah bangunan/obyek sakralnya. Pentingnya mempertahankan ruang sakral sebagai bentuk menjaga pluralisme masyarakat tradisional dalam konteks perencanaan keruangan.Penelitian ini bertujuan untuk menjawab permasalahan penelitian tentang perubahan ruang sakral Kuta dengan mempertimbangkan konsepsi ruang relasional. Dalam mencapai tujuan studi ini, maka dilakukan pengumpulan data baik primer maupun sekunder. Teknik analisis yang melandasi penelitian ini adalah analisis diskriptif, kualitatif dan interpretatif yang dilakukan sejak pengumpulan data dimulai.Berdasarkan kajian terhadap 7 (tujuh) jenis ruang-ruang sakral (Pura Dalem Kahyangan, Pura Dalem Tunon, Pura Pesanggaran, Sanggah, Pekarangan, Bale Banjar dan Catus Patha) pada 3 zona kesakralan (parahyangan, pawongan dan palemahan) di wilayah Desa Adat Kuta menunjukkan kecenderungan perubahan ruang. Terdapat beragam pola perubahan ruang sakral baik publik maupun privat terutama mencakup perubahan fungsi; perubahan tata letak dan orientasi; perubahan radius jarak dengan bangunan terdekat; perubahan ketinggian bangunan terdekat dan daya pandang bangunan terdekat ke arah bangunan/obyek sakralnya; serta perubahan lokasi ruang sakral. Perubahan tersebut mengindikasikan mulainya kemunculan kekuatan dominasi ekonomi dan politik yang mempengaruhi nilai-nilai sosial budaya lokal.
\end{abstract}

Kata Kunci: Ruang Sakral, Perkembangan dan Perubahan Ruang Sakral.

\section{PENDAHULUAN}

\section{Latar Belakang}

Perubahan budaya dapat mempengaruhi perubahan ruang (Maran, 2000; Lauer, 2003; Suparlan 1977 dalam Sukawati, 2008). Ruang merupakan simbolisasi dari kesepakatan bersama sebagai wadah untuk beraktivitas baik bekerja, rekreasi, ataupun bertempat tinggal, serta aspirasi/cara pandang hidup masyarakat dalam mengelola ruang secara bersama-sama. Perubahan ruang dapat memberikan pengaruh terjadinya perubahan pandangan dan pola aktivitas masyarakat serta timbulnya dampak sosial ekonomi dan sosial budaya yang bersifat menguntungkan maupun merugikan.

Ruang dapat dikelompokkan menjadi dua bagian sesuai dengan aktivitas masyarakat yang memanfaatkannya, yakni ruang sakral (berkaitan dengan kegiatan agama) dan ruang profan (berkaitan dengan kegiatan sosial) (Eliade, 2002; Dovey, 1979 dalam Sasongko, 2006; Santhayasa, 2010).

Perubahan ruang sakral merupakan relasi dari triad ruang menurut pandangan Levebvre, yakni relasi tiga elemen berupa ruang persepsi (perceived space) atau praktek ruang (spatial practice); ruang konsep (conceived space) atau representasi ruang (representation of space) dan ruang hidup (lived space) dan ruang representasi (representational space). Ketiga elemen tersebut saling berelasi dan saling mempengaruhi dalam mewujudkan perubahan ruang sakral.

Menurut Sukawati (2008) dalam konteks Bali, perubahan ruang sakral sangat terkait dengan Konsep Tri Hita Karana mengandung 
maksud filosofis untuk memperoleh keselarasan hidup dalam tiga hubungan, yaitu (1) manusia dengan Tuhan, (2) manusia dengan alam, dan (3) manusia dengan manusia, yang secara umum juga diterapkan pada tata ruang dan arsitektur tradisional Bali. Trilogi ini diberlakukan sebagai pedoman pembagian ruang wilayah pemukiman (Kawasan) yang dipilah menjadi tiga privacy sebagaimana azas dasar dari konsep Tri Hita Karana, yaitu spasial parhyangan (tempat suci desa), spasial pawongan (wilayah pemukiman penduduk desa) yang dalam penelitian ini ditransformasikan menjadi spasial pawongan dalam bentuk ruang-ruang atau wadah sosial, dan spasial palemahan (wilayah pendukung kehidupan/mata pencaharian penduduk desa).

Pentingnya mempertahankan ruang sakral sebagai bentuk menjaga pluralisme masyarakat tradisional dalam konteks perencanaan keruangan diungkapkan oleh Sudaryono (2006). Sudaryono menyampaikan pula bahwa pendekatan keruangan yang selama ini bersifat deterministik-rasionalistik telah banyak menuai kritik, khususnya karena ketidakmampuan mengakomodasi nilai-nilai pluralisme dan kepentingan masyarakat pada skala komunitas dan lokal. Oleh karena itu, Sudaryono (2006) mengungkapkan perhatiannya terhadap konsep penguatan ruang lokal termasuk ruang sakral sebagai sebagai bagian dari ruang-ruang lokal.

\section{Tujuan dan Sasaran}

Berdasarkan uraian sebelumnya maka tujuan penelitan ini adalah menjawab permasalahan penelitian tentang perkembangan dan perubahan ruang sakral Kuta. Adapun sasaran dalam penelitian ini yakni mengidentifikasi pola perubahan ruang sakral yang terjadi pada ketiga zona (zona parahyangan, zona pawongan, dan zona palemahan).

\section{METODA PENELITIAN}

Penelitian ini berupa studi kasus. Dari segi tempat pelaksanaannya, penelitian ini merupakan penelitian lapangan (field research) sehingga dapat ditemukan realitas atau fenomena yang terjadi pada ruang sakral Desa Kuta dalam bentuk gejala atau proses sosial. Lokasi penelitian ini adalah wilayah Desa Adat Kuta yang diarahkan sebagai salah satu kawasan wisata. Pemilihan lokasi penelitian didasari oleh pertimbangan-pertimbangan bahwa kawasan
Kuta telah menunjukkan perkembangan yang pesat. Pada penelitian ini, ruang sakral yang dikaji mencakup 7 jenis terdiri atas 4 jenis zona parahyangan, 2 jenis zona pawongan dan 1 jenis 1 zona palemahan. Penentuan informan dilakukan dengan teknik purposif (bertujuan), yaitu yang memiliki pengetahuan dan pengalaman berkaitan dengan perubahan ruang sakral di Desa Adat Kuta.

\section{HASIL DAN PEMBAHASAN}

1. Pura Dalem Kahyangan

Adapun kajian pola perubahan ruang pada Pura Dalem Kahyangan menunjukkan terjadi pengurangan radius jarak pura dengan bangunan terdekat, ketinggian bangunan terdekat melebihi batas, serta daya pandang bangunan terdekat yang tidak dibatasi dan menghadap langsung pura. Selain dominasi ruang ekonomi mulai muncul, tetapi respon negatif masyarakat juga besar untuk mempertahankan ruang sakral.

Dari uraian tersebut terdapat kontestasi ruang antara ruang sakral dan non sakral (jasa). Kontestasi ini menggambarkan pula masih lebih kuatnya pengaruh politik ekonomi yang mempengaruhi terjadinya perubahan ruang dan penurunan nilai sakral dari Pura Dalam Kahyangan dibandingkan dengan resistensi dari masyarakat adat dalam bentuk pemaknaan dan strategi dalam mempertahankan ruang sakralnya. Walaupun demikian struktur budaya dan adat serta aktivitas upacara masih tetap bertahan dilakukan di Pura Dalem Kahyangan. Dapat dikatakan ruang dominasi atau abstrak-yang dikembangkan Lefebvre sudah mulai terlihat, tetapi respon masyarakat sebagai bentuk apropiasi (penyelarasan) dan pertahanan niai lokal juga kuat.

2. Pura Dalem Tunon

Adapun kajian pola perubahan ruang sakral menunjukkan terjadi pengurangan radius jarak pura dengan bangunan terdekat, tetapi terjadi kesepakatan dengan pihak hotel mengenai radius jarak tersebut. Dominasi ruang ekonomi mulai muncul, tetapi terdapat kesepakatan dengan masyarakat mengenai radius jarak pura.

Perubahan ruang fisik pura Dalem Tunon diindikasikan dengan pengurangan radius 
jarak dengan bangunan hotel terdekat. Radius jarak sekarang menjadi $15 \mathrm{~m}$, dari semula yang lebih besar dari $15 \mathrm{~m}$. Permasalahan yang timbul pada saat awal (sekitar tahun 2000), yakni keinginan pihak hotel untuk memperluas bangunan hotel berada pada jarak yang lebih dekat (5$10 \mathrm{~m})$.

Dapat diungkapkan pula bahwa terdapat konsensus antara pihak puri dengan pihak pengelola pura keluarga mengenai keberadaan pura Dalem Tunon. Kondisi ditunjukkan dengan adanya kesepakatan tentang radius jarak pura dengan bangunan hotel terdekat.

3. Pura Pesanggaran

Adapun pola perubahan ruang pura Pesanggaran menunjukkan terdapat perubahan radius jarak pura dengan bangunan terdekat (hotel). Keberadaan pura Pesanggaran ini seperti pura lainnya juga lebih dahulu berdiri dibandingkan dengan hotel Kartika Plaza sebagai hotel yang berada paling dekat dengan pura. Sejalan dengan waktu, saat ini pura Pesanggaran tersebut menjadi bagian areal hotel Kartika Plaza.

Pada saat awal, radius jarak pura lebih besar dibandingkan saat ini, tetapi sejalan perkembangan hotel terjadi pengurangan radius pura. Saat ini berdasarkan wawancara dengan tokoh masyarakat diketahui bahwa jarak radius pura tersebut masih sesuai dengan aturan bishama, yakni bahwa pagar bangunan hotel terdekat berada tepat dengan penyengker/pagar pura. Selain itu, bangunan hotel Kartika Plaza tersebut juga masih sesuai dengan aturan bishama (maksimal 4 lantai).

4. Pura Keluarga ( Sanggah)

Terdapat perubahan ruang sakral pada beberapa pura keluarga akibat peningkatan kebutuhan ruang hunian khususnya penambahan anggota keluarga juga dorongan ekonomi untuk mengembangkan kegiatan produktif. Terdapat kecenderungan pemindahan lokasi sanggah dari lantai 1 ke lantai 2 atau 3. Terdapatnya upaya menambah daya tampung lahan tersebut sebagai akibat dorongan kekuatan sosial dan ekonomi dari pemilik pekarangan dalam memaknai ruang sanggah, tidak mempengaruhi pemaknaan masyarakat terhadap ruang sakral melalui upaya tetap mempertahankan ruang sakral.

5. Pekarangan

Kajian pola perubahan ruang sakral menunjukkan peningkatan kebutuhan perumahan akibat penambahan anggota keluarga serta dorongan ekonomi yang berimplikasi pada pemfungsian sebagian lahan perumahan untuk kegiatan produktif. Dengan kata lain, terdapat beberapa perubahan fungsi hunian serta penambahan fungsi komersial pada lahan pekarangan. Walaupun demikian, fungsi keagamaan (parahyangan) tetap bertahan pada zona yang seharusnya.

Berdasarkan penyebaran kuesioner dan wawancara diketahui bahwa perubahan ruang pekarangan dipengaruhi oleh perkembangan gaya hidup yang lebih modern (komersial) serta kebutuhan ruang tambahan akibat penambahan anggota keluarga.

Secara umum terdapat perubahan ruang pekarangan tetapi dengan tetap mempertimbangkan tata aturan adat sehingga perubahan kesakralan dapat diminimasi. Terjadinya perubahan atau penurunan kesakralan diwujudkan dengan posisi pekarangan dan bangunan yang dilarang menurut aturan adat. Upaya meminimasi dampak buruk tersebut dilakukan dengan melakukan upacara atau usaha-usaha lain secara adat.

Perubahan pekarangan akibat peningkatan kebutuhan penambahan ruang untuk kegiatan ekonomi, tetapi dengan tetap menjaga nilai kesakralan merupakan wujud warga adat yang masih teguh memegang aturan adat tetapi tetap adaptif terhadap perkembangan. Konsep desa-kala-patra menjadi dasar pertimbangan dalam perubahan ini.

6. Tempat pertemuan banjar (Bale Banjar) Kajian pola perubahan ruang menunjukkan adanya dorongan menambah pembiayaan kegiatan banjar melalui pemanfaatan sebagian ruang bale banjar untuk kegiatan komersial. Terdapat penambahan fungsi komersial pada areal banjar. Walaupun demikian fungsi bale banjar sebagai kegiatan agama, sosial dan budaya tetap terjaga. Terdapat kemunculan ruang sebagai dorongan ekonomi, tetapi ruang sakral masih bertahan. 
Penambahan fungsi perdagangan pada bale banjar selain fungsi utamanya dalam bidang sosial budaya, menunjukkan adanya upaya dari warga adat mencari pembiayaan untuk mendukung keberlangsungan kegiatan warga banjar termasuk kegiatan yang berhubungan dengan bale banjar. Upaya ini menunjukkan pula rasa memiliki warga banjar dalam menyelenggarakan kegiatan-kegiatan sosial budaya yang ada.

7. Catus Patha (perempatan agung)

Kajian pola perubahan ruang sakral, menunjukkan bahwa Catus Patha sekarang sebagai lokasi baru yang lebih layak dari segi adat dibandingkan pada lokasi sebelumnya. Pada Catus Patha tersebut keleluasaan ruang upacara masih terjaga, walaupun terdapat perkembangan ruang pada kawasan sekitarnya.

Catus patha (pempatan agung) Kuta mengalami perpindahan lokasi sekitar tahun 1990 an. Perubahan ini dilakukan karena lokasi sebelumnya kurang memenuhi syarat adat sebagai pempatan agung. Lokasi yang sekarang di perempatan Bemo Corner dianggap lebih sesuai sebagai Catus Patha.

Menurut Bagus Rai-sejarawan Kuta, perkembangan kegiatan jasa dan perdagangan di sekitar Catus Patha Bemo Corner tidak menjadi masalah, justeru melalui upacara nangluk merana (tolak bala) yang dilakukan akan dapat menghilangkan berbagai energi negatif kegiatan-kegaitan yang ada. Hal yang perlu dipertahankan adalah keleluasan ruang pada saat pelaksanaan upacara nya sehingga memudahkan pencapaian dan penggunaan catus patha.

Fungsi catus patha (pempatan agung) tidak berubah dan masih bertahan dapat digunakan untuk kegiatan upacara. Walaupun secara fisik kegiatan di sekitar perempatan yang termasuk pada kawasan pempatan agung tersebut berbeda dengan tata ruang adat yang lama.

\section{KESIMPULAN}

Adapun kesimpulan dalam penelitian ini yakni:

1. Berdasarkan kajian terhadap 7 (tujuh) jenis ruang-ruang sakral (Pura Dalem Kahyangan, Pura Dalem Tunon, Pura Pesanggaran, Sanggah, Pekarangan, Bale Banjar dan Catus Patha) pada 3 zona kesakralan (parahyangan, pawongan dan palemahan) di wilayah Desa Adat Kuta menunjukkan kecenderungan perubahan ruang. Terdapat beragam pola perubahan ruang sakral baik publik maupun privat terutama mencakup perubahan fungsi; perubahan tata letak dan orientasi; perubahan radius jarak dengan bangunan terdekat; perubahan ketinggian bangunan terdekat dan daya pandang bangunan terdekat ke arah bangunan/obyek sakralnya; serta perubahan lokasi ruang sakral.

2. Pada zona parahyangan pola perubahan umumnya berupa perubahan fungsi, berkurangnya radius jarak dengan bangunan terdekat, ketinggian bangunan terdekat dan pandangannya ke arah obyek sakral yang melebihi batas serta orientasi arah. Pada zona pawongan berupa perubahan fungsi, perletakan bangunan, orientasi vertikal dan pada zona palemahan berupa perubahan lokasi (catus patha). Perubahan tersebut mengindikasikan mulainya kemunculan kekuatan dominasi ekonomi dan politik yang mempengaruhi nilai-nilai sosial budaya lokal.

\section{Daftar Pustaka}

Sukawati (2008) Perubahan Spasial Desa Adat Ubud, Gianyar Bali, dalam Era Globalisasi: Sebuah Kajian Budaya, Program Doktor Kajian Budaya, Unud, Bali.

Sasongko, I. (2006) Pembentukan Ruang Berdasarkan Budaya Ritual. Disertasi. ITS: Surabaya.

Santhyasa, I Komang Gede Dan Wahyudi Arimbawa (2010): Perspektif Ruang Sebagai Entitas Budaya Lokal: Orientasi Simbolik Ruang Masyarakat Tradisional Desa Adat Panglipuran, Bangli-Bali, Local Wisdom-Jurnal Ilmiah Online, 2, (4): 01-09.

Sudaryono (2006) Paradigma Lokalisme dalam Perencanaan Spasial, Jurnal Perencanaan Wilayah dan Kota, Vol 17/No 1, April 2006. 